\title{
PENGARUH DISIPLIN,KOMPETENSI DAN KREATIVITAS MENGAJAR TERHADAP KINERJA GURU DI SEKOLAH MENENGAH PERTAMA (SMP) NEGERI 1 KARANG BARU KECAMATAN KARANG BARU KABUPATEN ACEH TAMIANG
}

\author{
Sutiyah \\ Universitas Islam Sumatera Utara \\ sutiyah.mm@gmail.com
}

\begin{abstract}
A nation no longer relies on the superiority of natural wealth, but rather on the excellence of human resources, one of which is educators (teachers) who are able to answer challenges very quickly. Education is basically an effort to develop human resources, even though efforts to develop human resources. Problems regarding teacher performance are problems that will always be faced by the management of an organization, therefore management needs to know the factors that can affect teacher performance With withdrawal techniques sample in total sampling, the sample in this study amounted to 30 people Middle School 1 Junior High School Teacher Karang Baru District Karang Baru Aceh Tamiang District. There was a significant effect of Discipline on the performance of teachers in the Junior High School 1 Junior High School at 0.353 on teacher performance so that it can be concluded adequate discipline can determine Teacher performance will also be high even though there are other variables that support to see the results of the performance of a teacher 0.281 but it is significant to conclude that Compensation can have high results if the teacher has good Compensation. Teacher creativity influences teacher performance by 0.351 and this significant indicates that Creativity can improve performance, Discipline, Compensation and Creativity together - a significant effect on teacher performance at SMP Negeri 1 Karang Baru First Middle School, is $24.6 \%$ while the remaining $75.4 \%$ is explained by other variables not included in this research model.
\end{abstract}

Keywords: Discipline, Competence, Creativity,

ABSTRAK : Suatu bangsa tidak lagi bertumpu pada keunggulan kekayaan alam, melainkan pada keunggulan sumber daya manusia, salah satunya tenaga pendidik (guru) yang mampu menjawab tantangan-tantangan yang sangat cepat. Pendidikan pada dasarnya merupakan suatu usaha pengembangan sumber daya manusia, walaupun usaha pengembangan sumber daya manusi.Permasalahan mengenai kinerja guru merupakan permasalahan yang akan selalu dihadapi oleh pihak manajemen sebuah organisasi, karena itu manajemen perlu mengetahui faktor-faktor yang dapat mempengaruhi kinerja guru Dengan teknik penarikan sampel secara total sampling maka sampel dalam penelitian ini berjumlah 30 orang Guru Sekolah Menengah Pertama (SMP) Negeri 1 Karang Baru Kecamatan Karang Baru Kabupaten Aceh Tamiang.Terdapat pengaruh yang signifikan Disiplin terhadap kinerja guru di Sekolah Menengah Pertama (SMP) Negeri 1 Karang Baru sebesar 0,353 terhadap kinerja guru sehingga dapat di simpulkan Disiplin yang memadai dapat menentukan Kinerja guru juga akan tinggi walaupun ada variable lain yang mendukung untuk melihat hasil kinerja seorang guru .Terdapat pengaruh yang Kompensasi terhadap kinerja di Sekolah Menengah Pertama (SMP) Negeri 1 Karang Baru sebesar -0.281 tetapi signifikan dapat disimpulkan bahwa Kompensasiakan dapat memiliki hasil yang tinggi jika guru memiliki Kompensasiyang baik.Kreativitas guru berpengaruh terhadap Kinerja guru sebesar 0,351 dan signifikan ini menunjukan bahwa Kreativitas dapat meningkatkan kinerja,Disiplin,Kompensasidan Kreativitas secara bersama - sama berpengaruh signifikan terhadap Kinerja guru diSekolah Menengah Pertama (SMP) Negeri 1 Karang Baru, adalah sebesar $24,6 \%$ sedangkan sisanya sebesar $75,4 \%$ dijelaskan oleh variabel lain yang tidak dimasukkan ke dalam model penelitian ini.

Kata Kunci : Disiplin, Kompetensi Dan Kreativitas 


\section{Pendahuluan}

Suatu bangsa tidak lagi bertumpu pada keunggulan kekayaan alam, melainkan pada keunggulan sumber daya manusia, salah satunya tenaga pendidik (guru) yang mampu menjawab tantangan-tantangan yang sangat cepat. Pendidikan pada dasarnya merupakan suatu usaha pengembangan sumber daya manusia, walaupun usaha pengembangan sumber daya manusia tidak hanya dilakukan melalui pendidikan khususnya pendidikan formal atau sekolah, akan tetapi sampai saat ini, pendidikan masih dipandang sebagai sarana dan wahana untuk pengembangan sumber daya manusia yang dilakukan dengan sistematis, programatis, dan berjenjang (Purwanto, 2003:76).

Untuk menaikkan taraf pendidikan yang berkualitas perlu adanya satu disiplin didalam suatu sekolah yang juga mempunyai peran penting dalam menentukan komitmen orang orang yang berada dalam sekolah .

Disiplin merupakan sikap, tingkah laku dan perbuatan yang sesuai dengan peraturan sekolah baik yang tertulis maupun yang tidak tertulis.Peraturan yang dimaksud termasuk absensi, lambat masuk, serta cepat pulangmya guru didalam mengajar, hal ini merupakan suatu sikap indisipliner guru yang perlu disikapi dengan baik oleh pihak manajemen sekolah.

Banyak yang mengartikan disiplin itu bilamana guru selalu datang serta pulang tepat pada waktunya.Pendapat itu hanya salah satu yang dituntut oleh organisasi.Oleh karena itu kedisiplinan dapat diartikan sebagai tingkah laku yang tertulis maupun yang tidak tertulis. (Hasibuan, 2003:212).

Disiplin kerja dapat didefeinisikan sebagai suatu sikap menghormati, menghargai, patuh dan taat terhadap peraturan-peraturan yang berlaku, baik yang tertulis maupun tidak tertulis serta sanggup menjalankannya dan tidak menggelak untuk menerima sanksi-sanksinya apabila ia melanggar tugas dan wewenang yang diberikan kepadanya. Siswanto, (2000 :291). Sedangkan menurut Rivai, Kedisiplinan merupakan fungsi operatif MSDM yang terpenting, karena semakin baik disiplin guru pada sekolah maka semakin tinggi prestasi kerja yang dapat dicapai. Rivai, (2004:824).

Dessler (2009:152) kompetensi adalah setiap imbalanyang diberikan kepada karyawan dan tim bul dari dipekerjakannya karyawan itu. Meskipun dalam praktiknya kinerja seseorang itu berbedabeda antara satu dengan yang lainnya dan namun kompetensi yang diberikan dengan bentuk uang atau barang adalah sarana untuk memenui kebutuhan mereka

Kompetensi yang akan diterima oleh mereka merupakan cermin dari apa yang telah mereka berikan atau kerjakan kepada organisasi atau perusahaan. Dengan memberikan kompetensi yang dilaksanakan secara benar dapatmemuaskan dan memoti,asi karyawan guna mencapai tujuan organisasi atau perusahaan dengan memberikan kompetensi sekolah menginginka

Para guru mencapai kinerja dalam bekerja yang yang akan memacu semangat dan kreativitas dalam bekerja sehingga dapat menunjukkan kinerjanya Menurut robbins (2000 ;156)

kinerja merujuk kepada sikap umum seorang individu terhadap pekerjaan yang

dilakukannya. Seorang dengan tingkat kepuasan

kerja tinggi menunjukan sikap

Permasalahan mengenai kinerja guru merupakan permasalahan yang akan selalu dihadapi oleh pihak manajemen sebuah organisasi, karena itu manajemen perlu mengetahui faktor-faktor yang dapat mempengaruhi kinerja karyawan. Faktor-faktor yang dapat mengetahui kinerja karyawan tersebut dalam manajemen perusahaan atau departemen dapat mengambil berbagai kebijakan yang diperlukan, sehingga dapat meningkatkan kinerja karyawan agar sesuai harapan Guritno B \& Waridin $(2005: 124)$.

Dalam Penelitian Husnan,(2005 ; 98) Variabel independen terdiri dari disiplin dan kompetensi kemudian variabel independennya adalah kinerja karyawan. Penelitian ini mengemukanan bahwa (a) terdapat hubungan yang sangat signifikan antara disiplin dengan kinerja guru (b) terdapat hubungan positif yang sangat signifikan antara disiplin dengan kinerja guru, (c) terdapat hubungan negatif yang sangat signifikan antara kompetensi dengan kinerja karyawan.

Hal yang sama dinyatakan oleh Simanjuntak,(2001; 108) dalam temuannya yang menujukan ada korelasi negatif antara disiplin dengan kinerja pada guru, yang berarti semakin tinggi disiplin maka akan semakin tinggi kinerja guru.Yang menjadi permasalahan Sekolah 
Menengah Pertama (SMP) karang baru Kecamatan Karang Baru Kabupaten Aceh Tamiang di adalah beberapa guru masih selalu mempengaruhi guru yang lain ketika guru tersebut tidak dapat menyelesaikan pekerjaan hal itu di karenakan adanya pekerjaan yang di berikan selalu di sepelekan sehingga tidak belajar dari kesalahan tetapi justru mempengaruhi orang lain untuk menyepelekan pekerjaan yang di berikan ,sehingga akibat dari perilaku guru tersebut guru yang lain tidak mampu memanage setiap pekerjaan dan dapat menyelesaikan pekerjaan yang dilakukan oleh guru dengan bekerja sesuaia aturan yang sudah ditetapkan sekolah permasalahan yang ada tidak adanya rendahnya didisiplin guru dalam mengajar dam mkompetensi yang di berikan tidak dapat meningkatkan kreativitas guru dalam mengerjakan satu pekerjaan dapat lebih di gunakan agar sehingga mempengaruhi kinerja guru dalam memberikan mata pelajaran di sekolah.

Adapun tujuan dari penelitian ini adalah untuk :

a. Mengetahui dan menganalisis pengaruh disiplin terhadap kinerja guru di SMP Negeri 1 Karang Baru Kecamatan Karang Baru Kabupaten Aceh Tamiang.

b. Mengetahui dan menganalisis pengaruh Kompetensi terhadap kinerja guru di SMP Negeri 1 Karang Baru Kecamatan Karang Baru Kabupaten Aceh Tamiang.

c. Mengetahui dan menganalisis pengaruh kretivitas mengajar terhadap kinerja guru di SMP Negeri 1 Karang Baru Kecamatan Karang Baru Kabupaten Aceh Tamiang.

d. Mengetahui dan menganalisis pengaruh disiplin, kompetensi dan kreativitas mengajar terhadap kinerja guru di SMP Negeri 1 Karang Baru Kecamatan Karang Baru Kabupaten Aceh Tamiang.

\section{Metode Penelitian}

\subsection{Lokasi Penelitian}

Penelitian ini dilakukan di Sekolah Menengah Pertama (SMP) Negeri 1 Karang Baru Jln. Bukit Bandar, Gampong Bundar Kec. Karang Baru, Kab. Aceh Tamiang, Provinsi Nangroe Aceh Darussalam 24476.

\subsection{Populasi}

Menurut Sugiyono (2007:55), populasi adalah wilayah generalisasi yang terdiri atas obyek/subjek yang mempunyai kuantitas dan karakteristik tertentu yang ditetapkan oleh peneliti untuk dipelajari dan kemudian ditarik kesimpulannya. Jadi populasi bukan hanya orang tetapi juga benda-benda alam yang lain. Populasi juga bukan sekedar jumlah yang ada pada objek/subjek yang dipelajari, tetapi meliputi seluruh karakteristik, sifat yang dimiliki objek/subjek itu. Dari pengertian tersebut, maka dapat disimpulkan bahwa populasi merupakan subjek penelitian dimana individu yang akan dikenai perilaku atau dapat dikatakan sebagai keseluruhan objek penelitian yang akan diteliti. Maka yang menjadi populasi dalam penelitian ini adalah GuruSekolah Menengah Pertama (SMP) Negeri 1 Karang Baru Kecamatan Karang Baru Kabupaten Aceh Tamiangyang berjumlah 30 orang.

\subsection{Sampel}

Menurut Sigiyono (2007:60), cara pengambilan sampel untuk subyek yang kurang dari 100, lebih baik diambil semua sehingga penelitiannya merupakan penelitian populasi. Selanjutnya jika jumlah subyeknya besar dapat diambil berdasarkan persentase dari populasi. Dengan teknik penarikan sampel secara total sampling maka sampel dalam penelitian ini berjumlah 30 orang GuruSekolah Menengah Pertama (SMP) Negeri 1 Karang Baru Kecamatan Karang Baru Kabupaten Aceh Tamiang.

\subsection{Definisi Operasional Variabel}

Variabel penelitian ini terdiri dari dua variabel, yaitu variabel bebas (Independent Variable) dan variabel terikat (Dependet Variable).

a. Variabel bebas (Independent Variable) merupakan variabel yang mempengaruhi atau yang menjadi sebab perubahannya atau timbulnya variabel dependen. Variabel independen penelitian ini adalah disiplin, kompensasi, kreativitas guru.

b. Variabel terikat (Dependet Variable).merupakan variabel yang dipengaruhi atau yang menjadi akibat karena adanya variabel independen. Dalam penelitian 
ini yang dijadikan sebagai variabel dependen kinerja guru.

\subsection{Teknik Analisa Data}

Teknik analisa data yang digunakan dalam penelitian ini adalah dengan melakukan beberapa pengolahan data yaitu dengan melakukan analisis regresi linear berganda, uji validitas, uji realibitas, uji hipotesis dan koefisien determinasi.

Tabel 1

Regresi Linear Berganda

Coefficients $^{\mathrm{a}}$

\section{Analisis dan Pembahasan \\ 3.1. Analisis Regresi Berganda}

Berdasarkan olahan data yang telah dilakukan, maka dapat diketahui bahwa model hubungan dari analisis regresi linear berganda ini dilihat dari tabel berikut ini:

\begin{tabular}{|l|l|l|l|l|l|}
\hline \multirow{2}{*}{ Model } & \multicolumn{2}{|l|}{$\begin{array}{l}\text { Unstandardized } \\
\text { Coefficients }\end{array}$} & $\begin{array}{l}\text { Standardized } \\
\text { Coefficients }\end{array}$ & T & \multirow{2}{*}{ Sig. } \\
\cline { 2 - 4 } & $\mathrm{B}$ & Std. Error & Beta & & \\
\hline constan & 24.212 & 11.386 & & 2.127 & .043 \\
X1 & .027 & .238 & .024 & .113 & .911 \\
X2 & .014 & .237 & .011 & .060 & .953 \\
X3 & .447 & .197 & .450 & 2.269 & .032 \\
\hline
\end{tabular}

@ Dependent Kinerja Guru

Tabel 1 menunjukkan persamaan regresi linear berganda penelitian ini adalah sebagai berikut :

$Y=\mathbf{2 4 . 2 1 2}+0,027 X_{1}-0,014 X_{2}+0,447 X_{3}$

Persamaan regresi linear berganda tersebut dapat diartikan sebagai berikut :

a. Jika variabel disiplin, kompetensi, dan kreativitas mengajar bernilai sama dengan nol, maka kinerja akan bernilai sebesar 24.212 satuan dengan kecenderungan mengalami penurunan.

b. Jika variabel ditingkatkan sebesar 1 satuan, maka kinerja guru akan meningkat sebesar 0,027 satuan. c. Jika kompetensi ditingkatkan sebesar 1 satuan, maka akan diikuti dengan peningkatan kinerja sebesar 0.014 satuan.

d. Jika kreativitas mengajar ditingkatkan 1 satuaan, maka akan diikuti dengan peningkatan kinerja sebesar 0,447 satuan.

\subsection{Uji Parsial (Uji t)}

\subsubsection{Uji t}

Uji ini dilakukan bertujuan untuk melihat tingkat signifikasi masing-masing variabel bebas terhadap variabel terikat yang dapat dilihat pada tabel di bawah ini :

Tabel 2

Uji t

Coefficients $^{\mathrm{a}}$

\begin{tabular}{|l|r|r|r|r|r|}
\hline \multirow{2}{*}{ Model } & \multicolumn{2}{|c|}{$\begin{array}{c}\text { Unstandardized } \\
\text { Coefficients }\end{array}$} & $\begin{array}{c}\text { Standardized } \\
\text { Coefficients }\end{array}$ & \multicolumn{1}{c|}{ T } & \multirow{2}{*}{ Sig. } \\
\cline { 2 - 4 } & \multicolumn{1}{|c|}{ B } & \multicolumn{1}{c|}{ Std. Error } & \multicolumn{1}{c|}{ Beta } & & \\
\hline (Constant) & 24.212 & 11.386 & & 2.127 & .043 \\
X1 & .027 & .238 & .024 & .113 & .911 \\
X2 & .014 & .237 & .011 & .060 & .953 \\
X3 & .447 & .197 & .450 & 2.269 & .032 \\
\hline
\end{tabular}

a. Dependent Variable: $Y$

Berdasarkan pada kriteria pengambilan keputusan bahwa apabila nilai probabilitas < nilai alpha sebesar 0,05, maka hipotesis diterima dan sebaliknya, apabila nilai sig. probabilitas > nilai 
alpha sebesar 0,05, maka hipotesis ditolak (Ghozali, 2001).

Tabel 3.2. diketahui bahwa nilai signifikansi dari disiplin $\left(\mathrm{X}_{1}\right)$ adalah 0.027 nilai ini lebih besar dari nilai alphanya yang sebesar 0.05.Dengan demikian dapat dinyatakan bahwa disiplin memiliki pengaruh signifikan terhadap Kinerja guru di sekolah Menengah Pertama (SMP) Negeri 1 Karang Baru Kecamatan Karang Baru Aceh Tamiang. Selanjutnya diketahui bahwa nilai signifikansi dari kompetensi $\left(\mathrm{X}_{2}\right)$ adalah 0.014 nilai ini lebih besar dari nilai alphanya yang sebesar 0.05. Dengan demikian dapat dinyatakan bahwa kompetensi memiliki pengaruh positif dan tidak signifikan terhadap kinerja guru di sekolah Menengah Pertama (SMP) Negeri 1 Karang Baru Kecamatan Karang Baru Aceh Tamiang .Selanjutnya di ketahui bahwa nilai signifikansi kreativitas mengajar $\left(\mathrm{X}_{3}\right)$ adalah 0,037 nilai ini lebih kecil dari 0,447 dengan demikian kreativitas mengajar memiliki pengaruh yang signifikan terhadap kinerja.

\subsubsection{Uji Simultan (Uji F)}

Uji serempak dilakukan untuk melihat tingkat signifikansi kedua variabel bebas secara bersama - sama berpengaruh terhadap variabel terikat. Hasil uji secara serempak dapat dilihat pada tabel dibawah ini : Tabel 3

\section{Uji F}

ANOVA $^{\mathrm{a}}$

\begin{tabular}{|l|r|r|r|r|r|}
\hline Model & \multicolumn{1}{|c|}{$\begin{array}{c}\text { Sum of } \\
\text { Squares }\end{array}$} & Df & Mean Square & F & Sig. \\
\hline Regression & 53.694 & 3 & 17.898 & 2.377 & $.000^{\mathrm{b}}$ \\
Residual & 195.773 & 26 & 7.530 & & \\
Total & 249.467 & 29 & & & \\
\hline
\end{tabular}

a. Dependent Variable: $Y$

b. Predictors: (Constant), X3, X2, X1

Tabel 3 menunjukkan bahwa nilai signifikansi adalah sebesar 0.000 Nilai signifikansi tersebut lebih kecil dibandingkan dengan nilai Alpha sebesar 0.05. Sehingga dapat disimpulkan bahwa secara bersama - sama disiplin,kompetensi dan kretivitas mengajar nberpengaruh signifikan terhadap Kinerja Guru di Badan Kepegawaian dan Pengembangan Sumber Daya Manusia Kabupaten Aceh Tamiang.

\subsubsection{Koefisien Determinasi $\left(\mathbf{R}^{2}\right)$}

Untuk dapat mengetahui besarnya Komitmen,Disipilindan Komitmen Organisasi dalam menjelaskan Kinerja Guru dapat dilihat pada koefisien determinasinya yang berada pada tabel 3.4. berikut :

Tabel 4

Koefisien Determinasi Model Summary

\begin{tabular}{|l|r|r|r|r|}
\hline Model & \multicolumn{1}{|c|}{$\mathrm{R}$} & $\mathrm{R}$ Square & $\begin{array}{c}\text { Adjusted R } \\
\text { Square }\end{array}$ & $\begin{array}{c}\text { Std. Error of the } \\
\text { Estimate }\end{array}$ \\
\hline 1 & $.496^{\mathrm{a}}$ & .246 & .188 & 3.17323 \\
\hline
\end{tabular}

a. Predictors: (Constant), X3, X2, X1

Berdasarkan pada tabel 3.4 diketahui bahwa nilai R-Square adalah sebesar 0,246. Artinya bahwa kompetensi, disiplin kerja dan komitmen organisasi mampu menjelaskan kinerja guru adalah sebesar $24,6 \%$ sisanya $75,4 \%$ dijelaskan oleh variabel lain yang tidak dimasukkan ke dalam model penelitian ini.

\section{Kesimpulan}

Berdasarkan pada penjelasan - penjelasan sebelumnya maka penelitian ini dapat disimpulkan sebagai berikut :

a. Terdapat pengaruh yang signifikan disiplin terhadap kinerja guru di Sekolah Menengah Pertama (SMP) Negeri 1 Karang Baru sebesar 0,353 terhadap kinerja guru sehingga dapat di 
simpulkan disiplin yang memadai dapat menentukan kinerja guru juga akan tinggi walaupun ada variable lain yang mendukung untuk melihat hasil kinerja seorang guru.

b. Terdapat pengaruh yang kompensasi terhadap kinerja di Sekolah Menengah Pertama (SMP) Negeri 1 Karang Baru sebesar -0.281 tetapi signifikan dapat disimpulkan bahwa Kompensasiakan dapat memiliki hasil yang tinggi jika guru memiliki Kompensasiyang baik.

c. Kreativitas guru berpengaruh terhadap kinerja guru sebesar 0,351 dan signifikan ini menunjukan bahwa kreativitas dapat meningkatkan kinerja.

d. Disiplin, kompensasi dan kreativitas secara bersama - sama berpengaruh signifikan terhadap kinerja guru di Sekolah Menengah Pertama (SMP) Negeri 1 Karang Baru, adalah sebesar 24,6\% sedangkan sisanya sebesar $75,4 \%$ dijelaskan oleh variabel lain yang tidak dimasukkan ke dalam model penelitian ini.

\section{DAFTAR PUSTAKA}

AA. Anwar Prabu Mangkunegara, 2014, Manajemen Sumber Daya Manusia Perusahaan, PT. Remaja Rosdakarya, Bandung.

Aditya Nur Pratama (2015), Pengaruh Lingkungan Kerja Dan Disiplin Kerja Terhadap Kinerja Karyawan PT. Razer Brothers

Anggraini, D., \& Nuraini, H. (2016). Hubungan Persepsi Siswa Terhadap Kompetensi Pedagogik Guru dengan Hasil Belajar Biologi Siswa Kelas X SMA Swasta Sinar Husni Medan Tahun Pembelajaran 2014/2015. Jurnal Pelita Pendidikan,

Daryanto,2010, Belajar dan Mengajar, Bandung: CV. Yrama Widya.

Gibson, J. L., Ivancevich, dan J. H. Donelly, Jr. (2010). Organisasi: Perilaku, Struktur, Proses (Terjemahan). Edisi Kedelapan. Jakarta: Binarupa Aksara.

Handoko, 2011, Manajemen Personalia dan Sumber Daya Manusia, BPFE, Yogyakarta.

Hariandja, Marihot Tua Efendi. 2012. Manajemen Sumber Daya Manusia. Jakarta: Grasindo.
Hasibuan, Malayu S.P. 2016. Manajemen Sumber Daya Manusia. Edisi Revisi. Jakarta: Penerbit PT Bumi Aksara.

Kunandar, (2009), Guru Profesional implementasi Kurikulum TingkatSatuan pendidikan (KTSP) dan sukses dalam Sertifikasi Guru, Jakarta: Rajawali Pers.

Malthis, 2012, Human Resource Management (edisi 10). Salemba Empat, Jakarta.

Mulyasa, E, 2008, Menjadi Guru Profesional Menciptakan Pembelajaran Kreatif dan Menyenangkan, Bandung: PT Rosdakarya.

Ngainun, 2009, Menjadi Guaru Inspiratif, Yogyakarta: Pustaka Belajar.

Pulungan, Intan \& Istarani, 2015, Ensiklopedi Pendidikan, Medan: CV. Iscom Medan.

Riyanto, Yatim, 2010, Paradigma Baru Pembelajaran sebagai Refrensi Bagi Gurul Pendidik dalam Implementasi Pembelajaran yang Efektif dan Berkualitas, Cetakan ke-2, Jakarta: Kencana.

Rivai, Veithzal. 2011, Manajemen Sumber Daya Manusia untuk Perusahaan: dari Teori ke Praktik, Jakarta : RajaGrafindo Persada

Rowen (2017), Pengaruh Disiplin kerja dan Loyalitas Terhadap Kinerja Karyawan CV. Tirta Agung Jaya Mandiri

Seifert, Kevin, 2012, Pedoman Pembelajaran \& Instruksi Pendidikan, Yogyakarta:IRCiSoD.

Sutrisno,Edi, 2013. Manajemen Sumber Daya Manusia, Cetakan Ketiga, Kencana Prenada Media Group, Jakarta.

Simamora, Henry. 2009. Manajemen Sumber Daya Manusia. Yogyakarta: SIE YKPN.

Sugiyono. 2009, Metode Penelitian Bisnis, CV Alfabeta, Bandung.

Sugiyono.2014.Metode Penelitian Pendidikan Pendekatan Kuantitatif, Kualitatif dan R\&D.Bandung:Alfabeta. _ _ 2010. Metode Penelitian Bisnis. Bandung: Alfabeta

Werther dan Darwis, 2010, Personnel Management and Human Resources, McGraw Hill Ltd, Tokyo 